\title{
Impacts of Economic Structural Change on Economic Growth: Forecasting Models and Policy Implications (A Case Study of Bến Tre Province)
}

\author{
Đinh Phi Hổ \\ University of Economics HCMC \\ dinhphiho@gmail.com \\ Nguyễn Khánh Duy \\ University of Economics HCMC \\ khanhduy@gmail.com
}

\section{ARTICLE INFO}

Article history:

Received:

Sep. 5, 2013

Received in revised form

Sep. 20, 2013

Accepted:

Sep. 25, 2013
Keywords:

economic structural change, regression model, Granger causality test, changes in Bến Tre's economic structure.

\section{ABSTRACT}

During the past ten years, economic growth in Vietnam changed positively in the direction of a modern industrial economy. Accordingly, economic structure also experienced changes in which manufacturing and service sectors accounted for a bigger share in the GDP. The government and most researchers are therefore very interested in economic structural change. This structural change in Vietnam as a whole requires the same change in local economies. However, some provinces did not catch up with the national development yet. Thus, in order to facilitate structural change on the whole economy, it is necessary to clarify what economic structural change aims at, and identify a quantitative model for measuring impact of such change, which becomes a real challenge to Vietnam's researchers and policy makers. To help solve this problem, the authors conducted a case study in Bến Tre to seek practical evidence. The results, based on regressive model, VAR model and Granger causality test, show that economic structural change impacts on the level of economic growth, labor productivity and the quality of life. This research also lays the foundation for a model for forecasting impacts of economic structural change. 


\section{INTRODUCTION}

Over the past ten years, Vietnamese economy has changed from a traditional agriculture to a modern industrial sector with an increasing share in the GDP from manufacturing-service sector. Shift in economic structure in Vietnam requires corresponding changes in local economies. However, several provinces could not keep pace with the national economy. To make an even impact, it is necessary to clarify what economic structural change aims at and to identify a quantitative model for measuring impacts of such change, which seems to become a challenge for Vietnam's researchers and policy makers. In order to help solve this problem, therefore, the authors conducted a case study in Bến Tre Province for seeking practical evidence. The paper focuses on two main aspects: (1) quantitative model for measuring impacts of economic structural change, and (2) some policy implications for local authorities.

\section{THEORETICAL BACKGROUND}

According to Lewis (1954), there is redundant labor in agricultural sector; and transfer of labor from agricultural sector to manufacturing and service ones is essential for economic development. This process can accelerate economic growth based on the growth of manufacturing and service sectors, and on intensive development of agriculture based on higher agricultural labor productivity.

The process of a nation's economic development has five stages of growth in order from low level to high one, including the traditional society, the preconditions for takeoff, the take-off, the drive to maturity, and the age of high mass consumption (Rostow, 1960). The take-off stage makes a turning point in change in the level of economic growth and is a target for developing countries. The transition from a low level of development to a higher one is also the change from a traditional agriculture to a transitional economy where modern and traditional elements are interwoven and then, to a modern industrial economy. This process also expresses a change from the economy where agriculture accounts for the biggest share in the GDP to a newer one where such a role is played by manufacturing - service sectors.

Based on the researches on many countries' development in the years 1930-1940, Fisher (1935) and Clark (1940) argued that the labor force in agricultural sector tends to fall when the economy moves from a low level of development to a higher one. The change in the level of economic growth (with income moving from a low level to a medium and then to a high level) depends on changes in the labor force in agriculture. 
The personal income is at a low level, a medium and a high level when the ratio of labor force in agriculture to the working population changes from $70 \%$ or higher to a level between $70 \%$ and $7 \%$, and to $7 \%$ or lower.

Based on researches on development of many countries in 1950-1973, Chenery (1979) posits that the share of agriculture in the GDP shows a downward tendency while the share of manufacturing sector rises when the economy moves to a higher level of development. Level of development ranked from a low to high (underdeveloped, developing and developed) depends on: (1) shares of agricultural and manufacturing sectors in the GDP, and (2) GDP per capita. An economy is considered as underdeveloped when the share of agriculture in the GDP is larger than that of manufacturing sector and GDP per capita is lower than US\$600. When the share of agriculture in the GDP is lower than that of manufacturing sector and GDP per capita is between US\$600 and US\$3,000, the economy is considered as a developing one. Finally, in a developed economy, contribution from the manufacturing sector is larger than that from agriculture and GDP per capita is greater than US $\$ 3,000$. Particularly, at the turning point when the share of agricultural sector is equal to that of manufacturing sector, the economy will change from underdeveloped level to developing level. Surpassing this turning point is a target for all underdeveloped countries.

According to Kuznets (1964), the contribution from agriculture to the GDP growth rate plays a decisive role in the early period of industrialization, but this role is less important in the long run.

Kuznets divides an economy into two sectors - agriculture and non-agriculture (all other sectors) - and introduces the following formula:

$$
C_{\mathrm{Y}}^{a}=\frac{1}{1+\frac{R_{n} \mathrm{Y}_{n}}{R_{a} \mathrm{Y}_{a}}}
$$

where:

$C_{\mathrm{Y}}^{a}$ Contribution from agricultural sector to GDP growth rate.

Ya: contribution from agriculture to the GDP 
Yn: contribution from non-agriculture sector to the GDP

Y: GDP

$\mathrm{Rn}$ : annual growth rate of non-agricultural sector.

Ra: annual growth rate of agricultural sector.

Two basic goals of economic development are to change from an economic structure of a traditional agriculture to one of modern economy and to enhance the quality of life (Thirwall, 1994).

- Economic structure is expressed in four aspects: GDP structure, labor structure, foreign trade structure and urbanization structure.

- The quality of life is expressed in three aspects: life expectancy, educational level and personal income.

Shift in economic structure from low level to high level is expressed in increasing shares of manufacturing and service sectors in the GDP; a decreasing labor force in agriculture; an enhanced openness of the economy (ratio of export value to the GDP); growth rate of urban population higher than natural growth of population; and improved life expectancy, educational level and personal income.

Mankiw (2003) and Park (1992) offer two arguments: (1) investment in human development creates a higher technological level for the economy in the long term and affects the GDP growth; and (2) labor productivity is a measurement of the quality of human resources and a decisive factor in enhancing personal income. Difference in personal income between developing countries and developed ones comes from difference in labor productivity, that is, in quality of human resources.

Thus, economic theory shows that shift in economic structure is an indispensable process of the economic development. This change must aim to enhance the level of economic growth, labor productivity and the quality of life. Based on empirical data in Vietnam, its economic structural change is measured by two scales: GDP structure and labor structure (Figure 1). The goal of this change is reflected in three aspects: level of economic growth (GDP per capita), labor productivity (GDP per laborer), and the quality of life. 


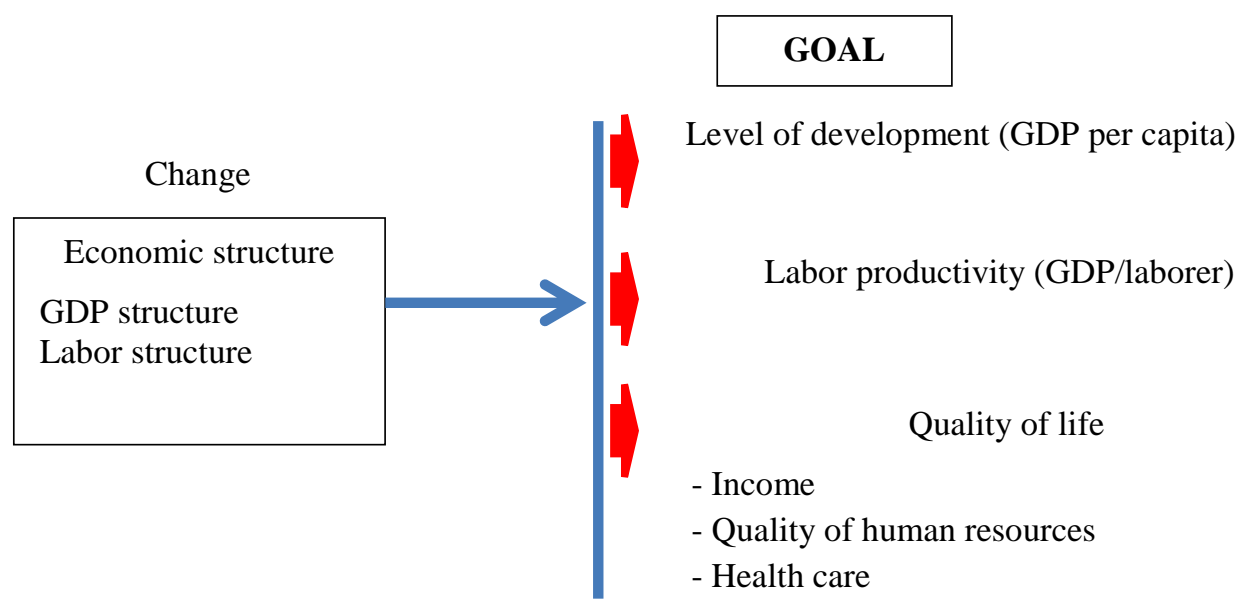

Figure 1: The Goal of Economic Structural Change

Income, quality of human resources and health care are measures of the quality of life.

\section{ECONOMIC STRUCTURAL CHANGE IN BẾN TRE PROVINCE}

\section{a. Changing Tendency of Economic Growth and Economic Structure:}

In the past decade, economic growth rate in Bến Tre was stable $(9.31 \%$ on average in the years 2001-2010) over two 5-year periods (9.38\% in the period 2001-2005 and 9.32\% in 2006-2010). In 2011, Bến Tre's economy attained a growth rate of over $8 \%$ in spite of bad effects from global recession. Table 1 shows that Bến Tre's growth rate was $6.2 \%$ and agricultural sector accounted for $43.7 \%$ of its gross product in 2000 and these figures were $8.7 \%$ and $18.2 \%$ respectively in 2011 . These figures reflect a significant change in effects of two sectors on Bến Tre's economic growth in the recent years. The decisive role in economic growth rate was the transforming from agricultural sector to non-agricultural sector (manufacturing and service) in this period.

Table 1: Shares in Economic Growth Rate in Bến Tre by Sector (2000-2011)

\begin{tabular}{lcccc}
\hline & \multicolumn{2}{c}{$\mathbf{2 0 0 0}$} & \multicolumn{2}{c}{$\mathbf{2 0 1 1}$} \\
\cline { 2 - 5 } & Growth rate & As \% & Growth rate & As \% \\
\hline GDP & 6.2 & 100.00 & 8.7 & 100.00 \\
Agriculture, forestry and fisheries & & 43.7 & & 18.2
\end{tabular}


Source: Bến Tre Statistical Department (2012) and authors' estimates.

In 2000, the traditional agriculture still accounted for $65 \%$ of Bến Tre gross product while manufacturing and service sectors were infant industries. Ten years later, however, there is an obvious change in economic structure from traditional economy to modern one with a drop in the share of agricultural sector in GDP from $66 \%$ in 2000 to $44 \%$ in 2010 and a sharp increase in the share of non-agricultural sector.

Table 2: Gross Product by Sector and GDP per capita

\begin{tabular}{llcc}
\hline & \multicolumn{2}{c}{ As \% } & Level of economic development \\
\cline { 2 - 4 } Year & $\begin{array}{c}\text { Agricultural sector } \\
(\mathbf{P a})\end{array}$ & $\begin{array}{c}\text { Non-agricultural sector } \\
(\mathbf{P n})\end{array}$ & $\begin{array}{c}\text { GDP per capita } \\
\text { (VNDmn, 1994 comparative price) }\end{array}$ \\
\hline 1999 & 67 & 33 & 2.9238 \\
2000 & 66 & 34 & 3.1212 \\
2001 & 65 & 35 & 3.3643 \\
2002 & 64 & 36 & 3.6547 \\
2003 & 62 & 38 & 3.9989 \\
2004 & 60 & 40 & 4.4311 \\
2005 & 57 & 43 & 4.9134 \\
2006 & 53 & 47 & 5.3991 \\
2007 & 51 & 49 & 5.9692 \\
2008 & 49 & 51 & 6.6011 \\
2009 & 47 & 53 & 7.1034 \\
2010 & 44 & 56 & 7.7678 \\
2011 & 43 & 57 & 8.5148 \\
\hline
\end{tabular}

Source: Bến Tre Statistical Department (2012) and authors' estimates

Table 2 shows that in the recent years, the level of economic growth in Bến Tre experienced significant changes. The higher level of development is (as seen in GDP per capita), the smaller the share of agricultural sector $(\mathrm{Pa})$ and the higher the share of nonagricultural sector (Pn). Figure 2 also shows that the share of agricultural sector in Bến 
Tre gross product was greater than that of non-agricultural sector before 2008 and this trend reversed after 2008 .

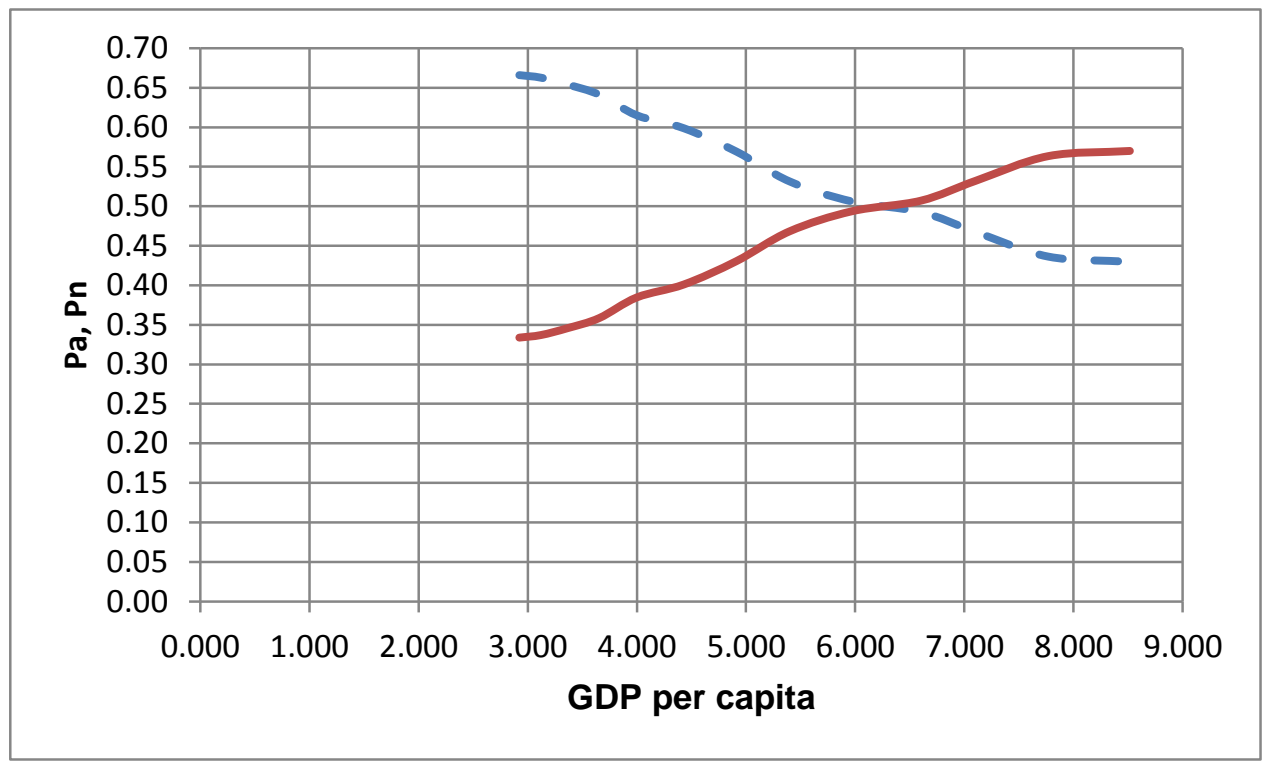

Figure 2: The Relationship Between Shares in Gross Product from IndustryService and Agriculture

According to Chenery's theory of economic structural change, level of economic development in Bến Tre moves to the developing stage with a turning point occurring in 2008 (share of agricultural sector in gross product equals to that of non-agricultural sector).

\section{b. Shift in Structure of Industries and Level of Development:}

One of the measures for shift in structure of industries is the share of each sector in GDP. Level of development is measured by GDP per capita. During industrialization, the share of non-agricultural sector in gross product should increase when the level of development is higher. Thus, a hypothesis is stated as follows:

$\mathrm{H}_{1}$ : An economic structural change with increasing share of non-agriculture sector in gross product produces a forward effect on level of development in Bến Tre.

$\mathrm{H}_{1}$ can be tested with the following regression equation:

$\mathrm{Y}=\mathrm{b}_{0}+\mathrm{b}_{1} \mathrm{Pn}$

Table 3: Results of the Model of the Relationship between Share of NonAgricultural Sector and GDP per capita 


\begin{tabular}{|c|c|c|c|c|c|}
\hline & \multicolumn{2}{|c|}{$\begin{array}{c}\text { Unstandardized } \\
\text { Coefficients }\end{array}$} & \multirow{2}{*}{$\begin{array}{c}\begin{array}{c}\text { Standardized } \\
\text { Coefficients }\end{array} \\
\text { Beta }\end{array}$} & \multirow[t]{2}{*}{$\mathbf{t}$} & \multirow[t]{2}{*}{ Sig. } \\
\hline & B & $\begin{array}{l}\text { Std. } \\
\text { Error }\end{array}$ & & & \\
\hline (Constant) & -4.146 & 2727.521 & & -6.388 & .000 \\
\hline $\begin{array}{l}\text { Share of non- } \\
\text { agricultural sector in } \\
\text { gross product }(\%)\end{array}$ & 21.269 & 6091.429 & .992 & 9.616 & .000 \\
\hline \multicolumn{6}{|l|}{ Adjusted $\mathrm{R}^{2}: 0,983$} \\
\hline ANOVA: $\mathrm{F}=92,4 ; \mathrm{S}$ &, 000 & & & & \\
\hline
\end{tabular}

The results show that shift in structure of industries has a significant effect on level of Bến Tre's economic development with reliability of over 99\%.

Estimated regressive equation: $\mathrm{Y}=-4.146+21.269 \mathrm{Pn}(1)$

\section{c. Shift in Structure of Industries and Labor Productivity:}

One of the measures for shift in structure of industries is the share of each sector in GDP. Labor productivity is measured by GDP per laborer. During industrialization, the share of non-agricultural sector in gross product should increase when the level of development is higher. Thus, a hypothesis is stated as follows:

$\mathrm{H}_{2}$ : An economic structural change with increased share of non-agriculture sector in gross product produces a forward effect on labor productivity in Bến Tre.

$\mathrm{H}_{2}$ can be tested with the following regression equation: $\mathrm{Y}=\mathrm{b}_{0}+\mathrm{b}_{1} \mathrm{Pn}$

Table 4: Results of the Model of the Relationship between Share of NonAgricultural Sector and GDP per laborer (VNDmn)

\begin{tabular}{|c|c|c|c|c|c|}
\hline & \multicolumn{2}{|c|}{$\begin{array}{l}\text { Unstandardized } \\
\text { Coefficients }\end{array}$} & \multirow{2}{*}{$\begin{array}{c}\begin{array}{c}\text { Standardized } \\
\text { Coefficients }\end{array} \\
\text { Beta }\end{array}$} & \multirow[t]{2}{*}{$\mathbf{T}$} & \multirow[t]{2}{*}{ Sig. } \\
\hline & B & $\begin{array}{l}\text { Std. } \\
\text { Error }\end{array}$ & & & \\
\hline (Constant) & -3.926 & .514 & & -7.646 & .000 \\
\hline
\end{tabular}




\begin{tabular}{|c|c|c|c|c|}
\hline $\begin{array}{l}\text { Share of non- } \\
\text { agricultural sector in } \\
\text { gross product }(\mathrm{Pn}, \%)\end{array}$ & 30.183 & 1.147 & .992 & 26.319 \\
\hline
\end{tabular}

Adjusted R ${ }^{2}: 0.983$

ANOVA: $\mathrm{F}=692,6,4 ;$ Sig. $=0,000$

Y: Dependent variable (labor productivity, GDP per laborer)

The results show that the shift in structure of industries has a significant effect on level of Bến Tre's labor productivity with reliability of over $99 \%$.

Estimated regression equation: $\mathrm{Y}=-3,926+30.183 \mathrm{Pn}(2)$

\section{d. Shift in Structure of Industries and Quality of Life:}

The quality of life is evident in three aspects: income (VND1, 000/person/year), quality of human resources (number of technicians-students in technical high school, university or college per 10,000 people) and health care service (number of doctors per 10,000 people).

During industrialization, the share of non-agricultural sector in gross product should increase when the level of development is higher. Thus, a hypothesis is stated as follows:

$\mathrm{H}_{3}$ : An economic structural change with increased share of non-agriculture sector in gross product produces a forward effect on quality of life.

$\mathrm{H}_{3}$ can be tested with the general regression equation: $\mathrm{Y}=\mathrm{b}_{0}+\mathrm{b}_{1} \mathrm{Pn}$

Table 5: Results of the Model of the Relationship between Share of Nonagricultural Sector (Pn) and the Quality of Life

\begin{tabular}{|l|l|}
\hline $\begin{array}{l}\text { Regression equation of economic structural change - income/ person/ year } \\
\mathrm{Y}=-17423,6+58576,34^{*} \mathrm{Pn}\end{array}$ & $\begin{array}{l}\text { Y: Dependent } \\
\text { variable } \\
\text { (income/ } \\
\text { person/ year) }\end{array}$ \\
$\begin{array}{l}\text { ANOVA: } \mathrm{F}=92,47 \text {; Sig. }=0,000 \\
* \text { Significance level of less than } 5 \%\end{array}$ & $\begin{array}{l}\mathrm{R}^{2}: 0,884 \\
\text { Pn: Independent variable (share of manufacturing-service sector in GDP) }\end{array}$ \\
\hline $\begin{array}{l}\text { Regression equation of economic structural change - Quality of human } \\
\text { resources }\end{array}$ & $\begin{array}{l}\text { Y: Dependent } \\
\text { variable } \\
\text { (technicians- } \\
\text { students in }\end{array}$ \\
\hline
\end{tabular}




\begin{tabular}{|c|c|}
\hline $\begin{array}{l}\text { Adjusted } \mathrm{R}^{2}: 0,39 \\
\text { ANOVA:F }=8,6 ; \text { Sig. }=0,013 \\
* \text { Significance level of less than } 5 \%\end{array}$ & $\begin{array}{l}\text { technical } \\
\text { schools, } \\
\text { universities \& } \\
\text { colleges/10,00 } \\
0 \text { people) }\end{array}$ \\
\hline $\begin{array}{l}\text { Regression equation of economic structural change }- \text { Health care } \\
\mathrm{Y}=-0,586+12,188^{*} \mathrm{Pn} \\
\text { Adjusted } \mathrm{R}^{2}: 0,729 \\
\text { ANOVA: } \mathrm{F}=33,3 \text {; } \mathrm{Sig} .=0,000 \\
\text { *Significance level of less than } 5 \%\end{array}$ & $\begin{array}{l}\text { Y: Dependent } \\
\text { variable } \\
\text { (doctors } / 10,00 \\
0 \text { people) }\end{array}$ \\
\hline
\end{tabular}

Table 5 shows that the shift in structure of industries has a significant effect on the quality of life in Bến Tre with reliability of over $99 \%$. Estimated regression models are presented in Equations (3), (4) and (5).

\section{e. Change in Labor Structure and Level of Development:}

One of the measures for labor structural change is the ratio of labor force in each sector to the working population. Level of economic development is measured by GDP per capita. During industrialization, the share of labor force in non-agricultural sector should increase when the level of development is higher. Thus, a hypothesis is stated as follows:

$\mathrm{H}_{4}$ : An economic structural change with increased share of labor in non-agriculture sector produces a forward effect on the level of development $(\mathrm{Y})$ in Bến Tre.

$\mathrm{H}_{4}$ can be tested with the regression equation: $\mathrm{Y}=\mathrm{b}_{0}+\mathrm{b}_{1} \mathrm{Pn}$

Table 6: Results of the Model of the Relationship between Labor force in Nonagricultural Sector and GDP per capita

\begin{tabular}{lccccc}
\hline & \multicolumn{2}{c}{$\begin{array}{c}\text { Unstandardized } \\
\text { Coefficients }\end{array}$} & $\begin{array}{c}\text { Standardized } \\
\text { Coefficients }\end{array}$ & t & Sig. \\
\cline { 2 - 5 } & B & $\begin{array}{c}\text { Std. } \\
\text { Error }\end{array}$ & Beta & & \\
\hline (Constant) & 0.409 & 0.35 & & 1.168 & 0.267
\end{tabular}


Ratio of labor force in non-agricultural sector to working population $\begin{array}{lllll}16.662 & 1.143 & 0.975 & 14.58 & 0\end{array}$ (PLn, \%)

Adjusted $\mathrm{R}^{2}: 0,956$

ANOVA: F $=212,5 ;$ Sig. $=0,000$

The results show that the shift in labor structure has a significant effect on level of level of development in Bến Tre with reliability of over $99 \%$.

Estimated regression equation: $\mathrm{Y}=0.409+16.662 \mathrm{Pn}$

A question for researchers of the causal relationship between changes in GDP and in labor structure is whether GDP affects labor force, or vice versa. To test this hypothesis, an $\ln$ - $\ln$ form of simple regression model is used to estimate the elasticity coefficient of working labor force by GDP. The following figure shows that LnGDP and LnLabour series are stationary because correlogram falls quickly to zero after two lags. Both stationary series are added to VAR model, optimal stationarity is determined and Granger causality test is conducted.

Figure 3: Determination of Optimal Stationarity and Granger Test Correlogram of LNLABOUR

Date: $11 / 22 / 12$ Time: 00:31

Sample: 19982011

Included observations: 14

\begin{tabular}{|c|c|c|c|c|c|c|c|c|c|}
\hline \multicolumn{2}{|c|}{ Autocorrelation } & \multicolumn{4}{|c|}{ Partial Correlation } & \multirow{2}{*}{$\frac{\mathrm{AC}}{\mathrm{O} 0.814}$} & \multirow{2}{*}{$\frac{\text { PAC }}{0.814}$} & \multirow{2}{*}{$\frac{\text { Q-Stat }}{11.425}$} & \multirow{2}{*}{$\begin{array}{c}\text { Prob } \\
0.001\end{array}$} \\
\hline 1 & & I & & $\square$ & 1 & & & & \\
\hline 1 & 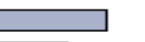 & I & $\square$ & 1 & 2 & 0.617 & -0.136 & 18.536 & 0.000 \\
\hline 1 & 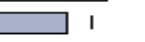 & I & $\square$ & I & 3 & 0.406 & -0.163 & 21.896 & 0.000 \\
\hline 1 & $\square \quad 1$ & 1 & $\square$ & 1 & 4 & 0.198 & -0.140 & 22.777 & 0.000 \\
\hline 1 & 1 & I & $\square$ & 1 & 5 & 0.004 & -0.130 & 22.777 & 0.000 \\
\hline
\end{tabular}




\section{Correlogram of LNGDP}

Date: 11/22/12 Time: 00:32

Sample: 19982011

Included observations: 14

\begin{tabular}{|c|c|c|c|c|c|c|c|c|c|}
\hline \multicolumn{2}{|c|}{ Autocorrelation } & \multicolumn{4}{|c|}{ Partial Correlation } & \multirow{2}{*}{$\begin{array}{l}\mathrm{AC} \\
0.802\end{array}$} & \multirow{2}{*}{$\frac{\text { PAC }}{0.802}$} & \multirow{2}{*}{$\frac{\text { Q-Stat }}{11.093}$} & \multirow{2}{*}{$\begin{array}{c}\text { Prob } \\
0.001\end{array}$} \\
\hline I & & I & & & 1 & & & & \\
\hline 1 & $\square$ & I & & I & 2 & 0.597 & -0.131 & 17.751 & 0.000 \\
\hline I & 1 & I & ए & I & 3 & 0.394 & -0.121 & 20.919 & 0.000 \\
\hline I & 1 & 1 & L & I & 4 & 0.193 & -0.143 & 21.749 & 0.000 \\
\hline 1 & 1 & I & & I & 5 & 0.008 & -0.119 & 21.751 & 0.001 \\
\hline
\end{tabular}

VAR Lag Order Selection Criteria

Endogenous variables: LNGDP LNLABOUR

Exogenous variables: $\mathrm{C}$

Date: 11/22/12 Time: 00:39

Sample: 19982011

Included observations: 11

\begin{tabular}{ccccccc}
\hline \hline Lag & LogL & LR & FPE & AIC & SC & HQ \\
\hline \hline 0 & 38.05875 & NA & $4.88 \mathrm{e}-06$ & -6.556137 & -6.483792 & -6.601740 \\
1 & 77.04014 & $56.70020^{*}$ & $8.67 \mathrm{e}-09^{*}$ & $-12.91639^{*}$ & $-12.69936^{*}$ & $-13.05320^{*}$ \\
2 & 79.85036 & 3.065692 & $1.21 \mathrm{e}-08$ & -12.70007 & -12.33834 & -12.92808 \\
3 & 83.53359 & 2.678714 & $1.76 \mathrm{e}-08$ & -12.64247 & -12.13606 & -12.96169 \\
\hline \hline
\end{tabular}

* indicates lag order selected by the criterion

LR: sequential modified LR test statistic (each test at $5 \%$ level)

FPE: Final prediction error

AIC: Akaike information criterion

SC: Schwarz information criterion

$\mathrm{HQ}$ : Hannan-Quinn information criterion

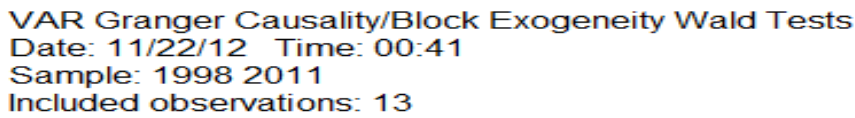

VAR Granger Causality/Block Exogeneity Wald Tests

Date: 11/22/12 Time: 00:41

Sample: 19982011

Included observations: 13

Dependent variable: LNGDP

\begin{tabular}{cccc}
\hline \hline Excluded & Chi-sq & df & Prob. \\
\hline \hline LNLABOUR & 1.744936 & 1 & 0.1865 \\
\hline \hline All & 1.744936 & 1 & 0.1865 \\
\hline Dependent variable: LNLABOUR & & \\
\hline \hline Excluded & Chi-sq & df & Prob. \\
\hline \hline LNGDP & 4.418588 & 1 & 0.0355 \\
\hline \hline All & 4.418588 & 1 & 0.0355 \\
\hline \hline
\end{tabular}


According to Figure 3, the optimal stationarity is 1. Granger causality test conducted at optimal stationarity (1 lag) finds a one-way relationship from $\ln G D P$ to $\ln L a b o r(\mathrm{P}$ value $=0.035$ ). The conclusion does not change when the lag rises to 2 or 3 (at a significance level of 5\%). Granger causality test shows enough statistical evidence to suggest that a one-way causal relationship from GDP to working labor force (GDP affects labor force) does exist, implying that GDP can explain changes in labor force. Thereby, this conclusion will be employed to find elasticity of working labor force by GDP in Bến Tre's economic sectors.

\section{f. Scenario for Forecasting Impact of Economic Structural and Labor Structural} Changes:

- Impact of economic structural change:

Based on predictions made by Master Plan for Socioeconomic Development in Bến Tre and regression equations of share of non-agricultural sector in the GDP, authors can forecast the impacts on socioeconomic development by 2015 and 2020.

Master Plan for Socioeconomic Development in Bến Tre anticipates that the share of manufacturing-service sector in the GDP will be $70.86 \%$ and $82.44 \%$ by 2015 and 2020 respectively. Thus, the results are presented in the following table:

Table 7: Forecasts of Economic Structural Change

\begin{tabular}{lccccc}
\hline & $\mathbf{2 0 1 0}$ & $\mathbf{2 0 1 5}$ & $\mathbf{2 0 2 0}$ & $\begin{array}{r}\mathbf{2 0 1 5} / \\
\mathbf{2 0 1 0}\end{array}$ & $\begin{array}{r}\mathbf{2 0 2 0} / \\
\mathbf{2 0 1 0}\end{array}$ \\
\hline $\begin{array}{l}\text { Share of non-agricultural sector in } \\
\text { GDP (\%) }\end{array}$ & & & & & \\
(Prediction in Bến Tre's Master & 55.97 & 70.86 & 82.44 & \\
$\begin{array}{l}\text { Plan) } \\
\text { Level of development }\end{array}$ & & & & & \\
(income/person/year) - VND1,000 & $14,397.60$ & $24,083.59$ & 30,86 & 1.7 & 2.1 \\
$\begin{array}{l}\text { GDP per capita- VNDmn. } \\
\text { (comparative 1994 price) }\end{array}$ & 7.77 & 10.93 & 13.39 & 1.4 & 1.7 \\
$\begin{array}{l}\text { GDP per laborer - VNDmn. } \\
\text { (comparative 1994 price) }\end{array}$ & 13.02 & 17.46 & 20.96 & 1.3 & 1.6 \\
Quality of human resources & 73.8 & 88.1 & 99.7 & 1.2 & 1.4
\end{tabular}


(technicians-students in technical

high school, university and

college/10,000 people)

Health Care

(doctors/10,000 people)

5.4

$8.1 \quad 9.5$

$1.5 \quad 1.8$

Data forecast for 2015 compared with 2010:

- Higher level of economic development with GDP per capita increasing by $140 \%$.

- Higher labor productivity with GDP per laborer increasing by $130 \%$.

- Better quality of life with personal income increasing by $170 \%$.

- Better quality of human resources with the number of technicians-students in technical high schools, universities and colleges/10,000 people increasing by $120 \%$.

- Better health care service with the number of doctors/10,000 people increasing by $150 \%$.

Data forecast for 2020 compared with 2010:

- Higher level of economic development with GDP per capita increasing by $170 \%$.

- Higher labor productivity with GDP per laborer increasing by $160 \%$.

- Better quality of life with personal income increasing by $210 \%$.

- Better quality of human resources with the number of technicians-students in technical high schools, universities and colleges/10,000 people increasing by $140 \%$.

- Better health care service with the number of doctors/10,000 people increasing by $180 \%$.

Equation (6) and predictions about level of economic development allow estimates of changes in labor structure by 2015 and 2020 as follows:

Table 8: Forecasting Changes in Labor Structure (\%)

\begin{tabular}{llccc}
\hline No. & Labor Structure (\%) & $\mathbf{2 0 1 0}$ & $\begin{array}{c}\text { GDP per capita } \\
\text { of } \mathbf{1 4 0 \%} \\
\text { higher than } \mathbf{2 0 1 0}\end{array}$ & $\begin{array}{c}\text { GDP per capita } \\
\text { of } \mathbf{1 7 0 \%}\end{array}$ \\
higher than 2010 \\
\hline I & Agricultural labor & 56.4 & 37.0 & 23.0 \\
II & Non-agricultural labor & 43.6 & 63.0 & 77.0
\end{tabular}




$\begin{array}{llrrr}1 & \text { Manufacturing and construction labor } & 17.3 & 25.0 & 30.6 \\ 2 & \text { Service labor } & 26.3 & 38.0 & 46.4 \\ \text { III } & \text { Total } & 100 & 100 & 100\end{array}$

To obtain the target of economic development by 2015 and 2020, the economic structure should be changed as follows:

Data forecast for 2015 compared with 2010:

- The labor force in agricultural sector reduces from $56.4 \%$ to $37 \%$ while the labor force in non-agricultural sector rises from $43.6 \%$ to $63 \%$. In 2015, the labor force in manufacturing-constructing sector and trading-service one are $25 \%$ and $38 \%$ respectively.

Data forecast for 2020 compared with 2010:

- The labor force in agricultural sector reduces from $56.4 \%$ to $23 \%$ while the labor force in non-agricultural sector rises from $43.6 \%$ to $77 \%$. In 2020, the labor force in manufacturing-constructing sector and trading-service one are $30.6 \%$ and $46.4 \%$ respectively.

\section{POLICY IMPLICATIONS}

\section{a. For Bến Tre Authorities:}

To obtain economic structural changes by 2020 as planned, full attention should be paid to the following aspects:

- Shift in structure of industries:

The following solutions can help to turn the economic structure in which agriculture accounts for $46 \%$ of gross product and manufacturing-service sector 54\% in 2010 to a more modern one with their shares equaling $18 \%$ and $82 \%$, respectively, by 2020 :

(1) Accelerating plans to improve and develop focal IPs in Châu Thành District and Bến Tre City, especially the ones that help expand the others, such as Giao Long IP with its links to ports and Giao Hòa IP by the Mỹ Tho River and Phước Long IP by the Hàm Luông River.

(2) Improving and developing commercial systems including trade centers, supermarkets and wholesale markets to facilitate exchange of goods and development 
of service sector in both provincial and district centers (Mỏ Cày Nam; Mỏ Cày Bắc; Ba Tri; Giồng Trôm; Châu Thành; Chợ Lách and Bình Đại for example).

(3) Increasing investment in and ensuring a sustainable development for Bến Tre traditional craft villages whose products have gained footholds in domestic and foreign markets, such as rice paper, sticky rice cracker, Phú Lễ spirits, mate, rug, coconut candy, handicraft made of coconut materials, seedlings, bonsai, and dried seafood.

(4) Upgrading north-south road networks connecting islets and east-west roads in each islet to improve transportation and trading services, thereby attracting more investors; and stabilizing supply of power to IPs, towns and tourist attractions.

(5) Revamping and developing historical sites, preserves, craft villages, ecotourism sites and high-class resorts to promote tourism thereby attracting foreign and local tourists who can spend much money and time at weekends and holidays.

- Shift in labor structure:

The following problems should be solved to reduce the labor force in agricultural sector from $56.4 \%$ in 2010 to $23 \%$ by 2020 :

(1) Adopting policies to orient labor in the agricultural sector toward IPs, foreign labor markets, traditional craft villages, and tourism-cultural services in Bến Tre.

(2) Introducing incentives for investment in vocational and technical training centers and job guidance service in cooperation with IP companies in order to increase the supply of skilled labor.

(3) Developing vocational colleges and high schools of provincial level and vocational training centers of district level to improve quality of direct labor; offering extra-preferential treatment to civic organizations, enterprises and individuals engaging in vocational training service in order to supply well-trained labor to craft villages, IPs and trading centers; and linking vocational training with job guidance and employment agencies to help laborers move from the agricultural sector to non-agricultural ones.

(4) Establishing and developing training services to serve labor export.

(5) Modernizing agricultural production by improving labor productivity, promoting commercial farming, and specializing production based on ecological advantages of each sub-region; and accelerating application of biotechnological advances and mechanization to agricultural production thereby facilitating shifts in labor structure.

\section{b. Broader Application of Forecasting Model:}


The major limitation of this forecasting model is its short time series and surveyed territory (in Bến Tre Province only). It is necessary to gather time series data in at least 21 years from different provinces in order to produce more reliable conclusions and forecasts. The model suggested by this research, however, can serve as a foundation for future studies

\section{References}

Bến Tre People's Committee (2011), Quy hoạch tổng thể phát triển kinh tế - xã hội tỉnh Bến Tre đến năm 2020.

Bến Tre Statistical Department (2000 - 2012), Niên giám thống kê

Chenery, H.B. (1979), Patterns of Development, 1950-1970, Oxford University Press for the World Bank.

Clark, C. (1940), Conditions of Economic Progress, London: Macmillan \& Co. Ltd.

Đinh Phi Hổ (2008), “When Vietnam Escapes Underdeveloped?” Economic Development, Number 163-March 2008.

Đinh Phi Hổ (2012), Phuơng pháp nghiên cứu định lương \& nhũng nghiên cứu thực tiê̂n trong Kinh tế phát triển - Nông nghiệp, Phương Đông Publisher.

Fisher, A.G.B. (1935), The Clash of Progress and Security, London: MacMillan \& Co. Ltd.

Kuznets, S. (1964), Economic Growth and the Contribution of Agriculture: Notes for Measurements, New York: McGraw - Hill.

Lewis, W. A. (1954), "Economic Development with Unlimited Supplies of Labour", Manchester School of Economic and Social Studies, 22, pp. 131-191.

Mankiw, N. Gregory (2003), Principles of Economics, New York: Worth Publisher.

Park, S.S. (1992), Tăng trương và phát triển (translation of Growth and Development: The Physical Output and Employment Strategy), Hà Nội.

Rostow, W.W. (1960), The Stages of Economic Growth, Cambridge: Cambridge University Press.

Thirlwall, A.P. (1994), Growth and Development with Special Reference to Developing Economies, London: Macmillan \& Co. Ltd. 